\title{
To separate or not to separate: Stanza boundaries and poetic structure
}

\author{
Barry P. Scherr*
}

\begin{abstract}
This article examines two related matters that have heretofore received little attention in the scholarly literature. The first is whether the division into stanzas shown on the page always reflects the thematic and formal structure of the poem. For instance, may 8-line stanzas with a repeated rhyme scheme (such as ababcdcd) in fact represent pairs of quatrains arbitrarily joined together? Conversely, are there cases when a poem written in couplets actually consists of 4-line or 6-line stanzas that have been divided? The second issue is whether a poet's decision to write verse in which stanzas are not demarcated on the page leads to works that differ in their formal features from those where the stanzas are (as is more typically the case) separated by blank lines. The latter portion of the article shows the effects of this decision in the verse of Aleksandr Kushner.
\end{abstract}

Keywords: Russian versification, stanzas, $20^{\text {th }}$-century Russian poetry, Kushner

This article offers some preliminary observations regarding two aspects of a single problem: are there effects on a poem that result from whether and how frequently a graphic division between rhyme units appears on the page? Oleg Fedotov (2002: 7) is no doubt correct in asserting that "the graphic layout [...] is not an empty formality, but an objective and, in the literal sense, evident sign of the author's will". The question to be explored here is whether a poet's will operates more or less autonomously in deciding if and where blank lines are to be placed between rhyme sets, or whether the choice carries with it certain implications for the poem's structure and forms. Granted, semantic considerations - a sense that line groupings of a certain length seem best suited for treating a poem's thematic element - may be an important factor. Nor it is it possible to discount the influence of tradition or of a poet's own previous practice. But here the focus will be on certain empirical - and often quite subtle - factors that may come into play within the context of a given poem or a poet's entire oeuvre.

The first matter to be considered arises when a rhyme pattern is repeated within the confines of a single stanza: the most common instance in Russian

\footnotetext{
* Author's address: Barry P. Scherr, Dartmouth College, Russian Department, 6085 Reed Hall, Hanover, New Hampshire 03755-3562.E-mail address: barry.scherr@dartmouth.edu
} 
verse consists of an 8-line stanza with two sets of alternating rhyme, ababcdcd. Is this in fact an 8-line stanza, or does the poem actually contain pairs of quatrains that happen to be joined together? Ernst Häublein (1978: 29) has stated: "Usually the unity of such [eight-line] stanzas is very precarious. In many cases, the rationale for choosing an eight-line instead of a four-line stanza is hard to see". The reverse situation also bears considering: do poets sometimes break up stanzas by inserting blank lines to create shorter units on the page? The prime examples in this case consist of couplets, which sometimes seem to have been formed from dividing 4- or even 6-line stanzas. The overall question, though, is whether the poet's will, in Fedotov's terms, comes to be expressed by any formal means beyond the presence or absence of spaces between the rhyme units - and whether those formal elements may sometimes suggest a different structure than what appears on the page.

The second matter concerns poems in which a consistent rhyme pattern appears throughout, but the stanzas run on continuously, with no blank lines demarcating their boundaries. The convention in Russian is to consider poems with eight or fewer undivided lines as "single-stanza" poems. ${ }^{1}$ However, regularly repeated rhyme schemes can be found in many longer undivided poems as well. The most prevalent pattern in this undivided verse - not surprisingly, given the predominance of the quatrain in Russian poetry - involves alternating rhyme in four-line units (ababcdcdefef...). Once again the function of blank lines - or their absence - between rhyme sets comes to the fore. While the decision whether or not to separate the stanzas may simply be up to the poet, it is nonetheless worth asking if the two alternatives have differing effects on a poet's writing - specifically, whether the formal features of verse written with, say, separated quatrains differ from those in works where the stanzas remains undivided on the page.

Any consideration of a poem's layout needs to contend with the possibility that a distortion of the "poet's will" has occurred during the process of a poem's transfer from manuscript to printed form. Kirill Vishnevsky has pointed out that the absence of a blank line indicating separate stanzas may be due to the interference of an editor or to a mistake during the typesetting process that is not subsequently corrected (Vishnevsky 1978: 51-52). Even though most authors, of course, take great care in overseeing the printing of their verse, errors do occur and are not always rectified in subsequent editions. Furthermore, a few poets - including, famously, Tiutchev - have been known

\footnotetext{
1 For his pioneering catalogue of Pushkin's stanzas Boris Tomashevsky placed poems containing from two to eight undivided lines in a separate category, and most researchers since then have accepted that distinction (Tomashevsky 1958: 138-147; see his note on p. 139).
} 
to display a striking indifference to the publication process. ${ }^{2}$ And these days even the most conscientious poets have little control over what appears on the internet, where the layout of a poem may well depend on the caprice of the person putting the work on line. For that matter, even the eventual position on the page can cause confusion. It is not unusual for a poem to be divided evenly between two pages so that it is impossible to be sure whether, for example, a 16-line poem was composed without any division at all or as two eight-line stanzas. Scholarly editions, for which the editors have gone back to the original manuscripts whenever possible, can reduce the likelihood of a lapse between the composing of a poem and its appearance in book form, but autographs of works have often not survived, and in any case such editions are usually not available for the works of contemporary authors. Thus a word of caution is in order, though the occasional incorrectly reproduced poem - assuming that such occurrences are indeed "occasional" - should not greatly alter the overall picture.

Two excerpts from poems by Mandel'shtam will help illustrate the range of factors that may come into play in considering the integrity of stanzas that contain a repeated rhyme scheme. The middle two stanzas of the 32 -line "Tristia" offer an instance where, despite the identical rhyme scheme in lines 1-4 and $5-8$, it seems highly likely that we are indeed dealing with an 8-line stanza:

$\begin{array}{ll}\text { Кто может знать при слове «расставанье» } & \text { A } \\ \text { Какая нам разлука предстоит, } & \mathrm{b} \\ \text { Что нам сулит петушье восклицанье, } & \mathrm{A} \\ \text { Когда огонь в акрополе горит, } & \mathrm{b} \\ \text { И на заре какой-то новой жизни, } & \mathrm{C} \\ \text { Когда в сенях лениво вол жуёт, } & \mathrm{d} \\ \text { Зачем петух, глашатай новой жизни, } & \mathrm{C} \\ \text { На городской стене крылами бьёт? } & \mathrm{d} \\ & \\ \text { И я люблю обыкновенье пряжи: } & \mathrm{A} \\ \text { Снуёт челнок, веретено жужжит. } & \mathrm{b} \\ \text { Смотри, навстречу, словно пух лебяжий, } & \mathrm{A} \\ \text { Уже босая Делия летит! } & \mathrm{b}\end{array}$

2 John Dewey's fine biography provides details on Tiutchev's generally careless attitude to the publication of his poems; for instance, when in 1836 he sent to Ivan Gagarin 65 poems to be considered for publication in Pushkin's Sovremennik, they were "in both draft and fair copies, often in more than one version. Tyutchev had made no effort to sort or edit the manuscripts" (Dewey 2010: 220). 
О, нашей жизни скудная основа,

C

Куда как беден радости язык!

d

Всё было встарь, всё повторится снова,

И сладок нам лишь узнаванья миг.

C

d

The second and third stanzas are representative of the whole, since the first two stanzas are in many ways alike, as are the last two. In the first two stanzas a comma appears after the fourth line, indicating continuity. Tomashevsky (1958: 55-56) noted that syntactic closure is a defining characteristic of stanzas, but, like certain other poetic features, such closure is a norm rather than an absolute requirement. Indeed, as Svetlana Matiash has shown, since the nineteenth century some poets have observed this norm more strictly and others less so. According to her figures, fewer than 3\% of Mandel'shtam's stanzas lack closure when the stanzas are separated (Matiash 2009; see especially pp. 194-197 and the data for Mandel'shtam on p. 196). Thus the presence of a comma after line 4 in two of the poem's four stanzas by itself already suggests that the poet was writing 8-line stanzas. The poem's second stanza (and the first of those quoted here) forms a single sentence, with its series of questions all referring to the same topic: not knowing what the new situation or the new day will bring. At the stanza's midpoint the "fire" (ogon') in line four relates to the image of the dawn in line five, thus further drawing together the first and second halves of the stanza semantically. At the same time there is an interesting change in the rhythm. Note that all four lines in the first half of the stanza are rhythmically the same, omitting stress on the fourth strong position, or ictus, in the line. The last four lines contain a mini-structure of their own: the fully stressed lines 6 and 7 are surrounded by two lines that omit stress on the first ictus. Thus a very faint hint at a difference between the two halves appears, but both the content and the punctuation after line four strongly point to a single 8-line stanza. Having established that expectation in the first two stanzas, Mandel'shtam can introduce strong syntactic breaks at the midpoint of his next two stanzas without great danger of their being read as quatrains. Furthermore, in both stanzas 3 and 4 - as illustrated in the second stanza of this quotation - he creates a 4-2-2 structure, with the punctuation at the end of line six "echoing" that at the end of line four, thereby giving rise to the sense that they essentially belong together. In the case of this stanza, an additional unifying feature is the reappearance of the rhyme vowel from lines two and four in lines six and eight. Finally, and perhaps less obviously, the word boundaries in lines four and six make them rhythmically identical (Уже́ / Куда́; боса́я / как бе́ден; Де́лия / ра́дости; лети́т / язы́к), thereby further helping to draw the two halves of the stanza together. 
A more ambiguous situation occurs in "Vek", another poem with 32 lines, divided on the page into four stanzas. The first two stanzas are given below:

$\begin{array}{ll}\text { Век мой, зверь мой, кто сумеет } & \mathrm{A} \\ \text { Заглянуть в твои зрачки } & \mathrm{b} \\ \text { И своею кровью склеит } & \mathrm{A} \\ \text { Двух столетий позвонки? } & \mathrm{b} \\ \text { Кровь-строительница хлещет } & \mathrm{C} \\ \text { Горлом из земных вещей, } & \mathrm{d} \\ \text { Захребетник лишь трепещет } & \mathrm{C} \\ \text { На пороге новых дней. } & \mathrm{d} \\ & \\ \text { Тварь, покуда жизнь хватает, } & \mathrm{A} \\ \text { Донести хребет должна, } & \mathrm{b} \\ \text { И невидимым играет } & \mathrm{A} \\ \text { Позвоночником волна. } & \mathrm{b} \\ \text { Словно нежный хрящ ребенка } & \mathrm{C} \\ \text { Век младенческой земли - } & \mathrm{d} \\ \text { Снова в жертву, как ягненка, } & \mathrm{C} \\ \text { Темя жизни принесли. } & \mathrm{d}\end{array}$

In these, as in the other two stanzas, there is a clear break after the fourth line, and each four-line unit seems reasonably well contained. It is hard to find an obvious reason for the lines to be arranged in 8-line stanzas rather than quatrains, and this appears to be a poem in which the length of the stanza simply reflect the poet's will. Still, it is worth looking a little more closely to see whether there are any formal signs that Mandel'shtam had eight-line sections in mind as he was composing the poem. A possible approach in this case is to consider the stanza rhythm - the stressing analyzed according to each line's position within the stanza. This topic has received only occasional attention in the scholarly literature, with the most extensive survey of the topic to date found in an article by M. L. Gasparov. He looked primarily at quatrains, but he also provided some data for 8-line trochaic tetrameter stanzas of the nineteenth century. Even though that period precedes the writing of this poem, the findings can still provide a benchmark. Gasparov (1989: 142) discovered that the rhythm of these stanzas tended to form double quatrains: the highest average stress is on the first line, then average stressing drops rapidly from lines two to four, stress on the fifth line rises to be the second highest for the poem, and then it falls off more gradually over lines 6-8. "Vek" is too short to allow for a valid statistical analysis, but its general pattern does not deviate too far 
from that outlined by Gasparov. For the entire four stanzas of the poem, the first line displays the most frequent stressing, and then there is a drop over the next three lines, with three and four having the fewest stresses. Lines five through eight are relatively even, with the same amount of stressing on lines two, five and seven, which all tie for second in the number of stresses. The most striking feature is the use of fully stressed lines to begin three of the four stanzas in the poem: it is as though Mandel'shtam clearly wants to mark the beginning of each stanza. Furthermore, in the first stanza lines 4 and 5 both omit stress on the penultimate ictus, thereby creating a rhythmic similarity and blurring any border between the quatrains. In the second stanza he emphasizes the fifth line by making it fully stressed, but in this case the rhyme in lines five and seven, ending with an unstressed "-ka", contains an echo of the rhyme vowel in lines two and four. The third stanza begins with a pair of fully stressed lines («Чтобы вырвать век из плена, / Чтобы новый мир начать»), and the sense of a strong opening is further emphasized by the anaphora as well as the identical word boundaries. Thus, even though the most obvious features (the repeated rhyme scheme, the syntactic break after line 4 in every stanza) point to underlying quatrains as the actual structural units of this work, the strong rhythmic beginnings to the stanzas as well as the similarity of the stanza rhythm to that of other poems composed in trochaic tetrameter 8-line stanzas suggest that Mandel'shtam was in some ways emphasizing 8-line divisions during the writing of the poem.

The reverse phenomenon involves poems containing short stanzas that seem to have been carved out of larger units: that is, certain structural features of the poem indicate that the poem actually consists of longer stanzas than those presented on the page. This situation arises most often with couplets. Below in its entirety is the first poem from Akhmatova's cycle "Cinque":

Как у облака на краю,

Вспоминаю я речь твою,

А тебе от речи моей

Стали ночи светлее дней.

Так отторгнутые от земли,

Высоко мы, как звезды, шли.

Ни отчаянья, ни стыда

Ни теперь, ни потом, ни тогда. 
Но живого и наяву,

Слышишь ты, как тебя зову.

И ту дверь, что ты приоткрыл,

Мне захлопнуть не хватит сил.

On the page, this poem appears to be in six 2-line stanzas rhyming aa. Could it just as well, especially considering the lack of a clear syntactic break after the poem's second line, consist of three 4-line stanzas rhyming aabb? In this case, I would argue, certain features strongly point to the 2 -line stanza. Not only do the spaces every two lines reflect the will of the poet, but so does the selfcontained nature of these units, expressed most strongly, perhaps, in the 5 -fold use of the word $n i$ in lines 7-8, but also in the focused imagery elsewhere, such as that of earth and stars in lines 5-6 and the door in lines 11-12. I would add to this a rhythmical factor. The poem is written in 3-stress dol'nik verse, with a 2-syllable anacrusis that sometimes bears an extra stress. Note, though, that the rhythm of the first line and that of the second line differ. The first line of each pair usually has just two stressed ictuses; the two times when this line has a third stress it is followed by two syllables before the final ictus (lines 3 and 11). Thus the underlying pattern for the odd lines is $\mathrm{xxXxXxxX}$ - though line 5 has an extra syllable, making it equivalent to anapestic trimeter. As for the second line of each couplet, all the ictuses are stressed, and the pattern in five of the six even lines is $\mathrm{xxXxxXxX}$, with a one-syllable interval between the final two ictuses. The single exception, the eighth line, is again in anapestic trimeter. Thus a total of 14 metrical stresses occur in the first lines of the couplets and 18 in the second. In addition, the two strong hypermetrical stresses on the first syllable (stali in line 4; slyshish' in line 10) appear in those second lines. This heavier stressing on the even lines further indicates that Akhmatova was creating a kind of back and forth rhythm between each pair of lines, thereby strengthening the notion that she was indeed thinking in terms of couplets even though the use of Tak to begin line 5 and No to begin line 9 vaguely imply 4-line groupings in terms of the thematic structure.

Determining whether couplets form the predominant structure of a poem can be difficult in the case of Gumilev, who wrote some twenty poems with 2-line stanzas on the page. The pre-1916 poems (through the collection Kolchan) are always in paired masculine rhyme, generally consist entirely or at least primarily of syntactically closed couplets, and in all but two cases contain a total number of lines that is not divisible by four. All this argues for 2-line stanzas; yet among these earlier works Gumilev has poems apparently written in couplets where the lack of strong syntactic breaks between stanzas 
calls that structure into question. Consider the 26-line " $U$ kamina", where the clearest syntactic boundaries occur after lines 4, 10, 12, 14, 18 and 24. Gumilev similarly has irregular breaks in later poems, such as "Somalijskij poluostrov", which, considering only the syntax, divides irregularly into units of four or six lines (4-6-6-6-4-4-6-6). In these and other instances Gumilev seemed to have felt confined by the couplet form and to employ far more syntactically open stanzas than he did with longer stanza forms. In the case of "Rassypajushchaja zvezdy" there is some justification for arguing that he was essentially writing quatrains. Below are the first eight of the sixteen lines:

Не всегда чужда ты и горда

И меня не хочешь не всегда, -

Тихо, тихо, нежно, как во сне,

Иногда приходишь ты ко мне.

Надо лбом твоим густая прядь,

Мне нельзя её поцеловать,

И глаза большие зажжены

Светами магической луны.

The punctuation in this poem has varied; the version here is from the recent edition of Gumilev's complete works (1999: 169). ${ }^{3}$ Note the absence of a full syntactic break after the odd and before the even numbered stanzas: that is, sentences end only after lines 4, 8, 12 and 16; after lines 2, 6 and 10 there are commas, and line 14 has no punctuation at all. The syntax, then, strongly suggests quatrains. Furthermore, if one breaks the poem into quatrains and then counts the number of stresses in each line of the quatrain over the four resulting stanzas, it turns out that lines 4, 8, 12 and 16 lines have a total of 13 stressed ictuses, making this line of the quatrain the most lightly stressed in the poem as a whole. Indeed, even over a poem as short as this, the frequency of stressing, considering the lines in groups of four, closely matches the stanza

3 The "Biblioteka poeta" edition (1988: 269) contains a period after both lines 5 and 6 . The commas found in the Polnoe sobranie sochinenij seem more likely. Another difference occurs in line 14, which has no punctuation in the Polnoe sobranie sochinenij but a comma in the Biblioteka poeta volume. However, in both editions the punctuation at the conclusion of every fourth line clearly marks the end of a sentence. 
rhythm found by Gasparov (1989: 144) in trochaic pentameter quatrains. ${ }^{4}$ In short, it is hard to avoid the conclusion that Gumilev was essentially writing 4-line stanzas rather than couplets.

One of the most interesting cases occurs in "Les". The number of lines (30) is not divisible by four, but the clear syntactic breaks occur after lines $4,8,12$, 18, 22 and 26, implying an overall symmetrical structure of 4-4-4-6-4-4-4: six 4-line stanzas, with a single 6-line stanza in the center. (Thematically, the strongest division occurs after line 18.) As in "Rassypajushchaja zvezdy" only the rhyme scheme - with each pair of lines rhyming aa - suggests the existence of couplets. ${ }^{5}$ Thus, just as longer stanzas may for all practical purposes seem to consist of shorter stanzas written together on the page, so too may relatively short stanzas represent longer stanzas that have been arbitrarily divided.

The second matter relating to the layout of verse concerns the poet's decision to separate the rhyme units graphically into stanzas or to present all the lines as a continuum. While the great majority of Russian poetry with a regularly repeated rhyme scheme uses blank lines to demarcate stanzas, a not insignificant number of exceptions occur. Does the decision about whether to separate the stanzas on the page have other implications as well?

I have touched on this issue in an article dealing with the poetry of Evgeny Rein, one of the few poets to write the majority of his poems without blank lines between the rhyme sets (Scherr in press-a). The corpus of material comprised 293 lyric poems in the largest single collection of his verse (Rein 2001). All but 30 of the poems employed stanzas, and of the works in stanzas 97 had blank lines between the stanzas on the page and 166 did not. This latter figure represents $63 \%$ of the stanzaic poems, an unusually high proportion.

The most striking difference between those two sets of poems is, not unexpectedly, the syntactic integrity of the stanzas. Of the collection's 97 poems in the first category only once is a stanza left syntactically open at the end a clear indication that when Rein separates his stanzas, he feels the end of the stanza should coincide with the end of a sentence. Some of the poems that appear undivided on the page also contain clear syntactic breaks after each rhyme unit, but many lack one or more breaks. Thus one difference is

4 For 19th-century trochaic pentameter verse rhyming AbAb Gasparov noted that the first and third lines were stressed equally, the frequency of stress on the second was slightly lower than on the odd lines, and the fourth was stressed least frequently of all. If this poem is read as consisting of four 4-line stanzas; then the number of stressed ictuses on each line is 16, 15, 16 and 13, matching the pattern detected by Gasparov.

5 For a more extensive treatment of "Les" and of Gumilev's couplets in general, see Scherr in press-b. 
clear: when Rein writes poems without space between the rhyme sets, he is far more inclined to leave them syntactically open. Had Svetlana Matiash (2009: 195-197) included Rein in her examination of syntactic closure in poems with graphically divided stanzas, the near absence of open stanzas in the 97 poems that fall into this category would cause Rein's practice to resemble that of the eighteenth century, when syntactic closure was a virtual necessity. Rein apparently was more or less consciously limiting his syntactically open stanzas to those poems where the stanzas are not separated.

The frequency of syntactic openness, however, is not the only difference. When Rein divides his verse on the page into regular quatrains, his practice tends to be formally conservative. One-third of those poems are written in iambic tetrameter or pentameter verse, while the other meters he employs frequently are among those found most commonly in Russian poetry: trochaic tetrameter, anapestic and amphibrachic trimeter. When he writes verse that is not divided on the page, he becomes more venturesome, using a wider range of meters and, in a significant handful of poems, composing complex long lines - such as trochaic heptameter and octameter, amphibrachic and dactylic pentameter. The percentage of poems displaying non-classical meters (dolniki, logaoedic and accentual verse) rises from about $11 \%$ when the stanzas are graphically divided to $19 \%$. Even his rhyming becomes bolder: approximate rhymes appear in much of his poetry, but the most radical instances of approximate rhyme are concentrated in the undivided verse. At least in terms of formal experimentation, his divided verse tends to be rather conservative, while the absence of graphic divisions seems to have given him a license for greater experimentation.

Rein of course is far from the only poet to write repeated rhyme schemes without dividing them on the page. Among nineteenth-century poets the differences between divided and undivided verse appear to have been less extreme. That said, Baratynsky, who wrote about a dozen poems in undivided quatrains, does on occasion leave some of his rhyme sets syntactically open when he uses this format. ${ }^{6}$ Thus in "Ot"ezd", a 32-line poem in alternating iambic tetrameter and trimeter lines, the first three rhyme sets end with a semi-colon, and the penultimate rhyme set with a comma. In "Svoenravnoe prozvan'e" three of the five boundaries between rhyme sets conclude with a semi-colon or comma. When Baratynsky divides his verse on the page, fewer

\footnotetext{
6 Note that the metrical handbook for Baratynsky lists more than 50 works in undivided quatrains; however, the great majority of these are 8-line poems, which, as noted above, are regarded by most scholars as "single-stanza" compositions. For a list, see Shakhverdov 1979: 319-320.
} 
than $4 \%$ of his stanzas are syntactically open; clearly, he felt the freedom to treat his rhyme sets differently when they were not separated by spaces. ${ }^{7}$

More recent poets, though, tend to exhibit additional differences between their divided and undivided verse. While Aleksandr Kushner, a close contemporary of Rein, has most often placed blank lines between his identical stanzas, he has also composed a significant amount of poetry in which the stanzas are continuous on the page. An extensive study of the poetry that he had published in collections though 2006 showed that, out of 1300 poems in total, nearly 850 have stanzas that are divided by blank lines and just under 150 are written in stanzas that are not separated (Laletina, Lutsiuk, Tver'ianovich 2008; see esp. Table 21-U, pp. 579-603, for the data mentioned in this paragraph). Both kinds of verse employ a broad metrical repertoire, albeit with some interesting differences in usage. Whether or not his stanzas are divided, Kushner, like most Russian poets, favors the quatrain, most often with alternating masculine and feminine rhyme ( $\mathrm{AbAb}$ or $\mathrm{aBaB})$, but sometimes with all feminine $(\mathrm{ABAB})$ or all masculine $(\mathrm{abab})$ rhymes alternating. The frequency of quatrain types differs, sometimes sharply, depending on whether or not the stanzas are separated. In the divided verse the number of poems in $\mathrm{AbAb}$ and $\mathrm{aBaB}$ are about equal, with a slight preference for the latter, but when the stanzas are not divided almost twice as many poems are in AbAb. There are about equal numbers of poems with quatrains in all feminine or all masculine alternating rhymes in the divided verse, whereas in the undivided verse about twice as many poems in all feminine rhymes are found. When the stanzas are separated, about $10 \%$ of the poems with alternating feminine and masculine rhyme employ iambic pentameter. The same is true for the undivided $\mathrm{AbAb}$ poems, but for those in $\mathrm{aBaB}$ the frequency rises to a little over $25 \%$. Kushner is the opposite of Rein in that his undivided verse tends to employ longer metrical forms less often than his poems in which the stanzas are demarcated. Of the 131 undivided poems written in the four types of quatrain most favored by Kushner ( $\mathrm{AbAb}, \mathrm{aBaB}, \mathrm{ABAB}, \mathrm{abab})$, just one is in amphibrachic pentameter and two in anapestic pentameter; for the 453 divided poems employing one of these four combinations of line endings, the figures for these two meters are 18 and 28 , or $4 \%$ and a little over $6 \%$.

However, the most notable aspect of Kushner's approach to undivided verse is the manner in which it evolves over the years. In early poems, such as "Uroki fiziki" or "Osen", he tends to be fairly conservative. Both poems

7 For the frequency of open stanzas in Baratynsky's divided verse, see the table in Matiash 2009: 195. 
are written in iambic tetrameter, rhyme $\mathrm{AbAb}$ throughout, and have a strong syntactic break every four lines. Even in the few instances when he introduces commas at the ends of his four-line units, he is careful to make each quatrain integral. Two such boundaries occur in the concluding portion of "Vozdukhoplavatel'nyj park":

$\begin{array}{ll}\text { Чтоб нам летать и удивляться: } & \mathrm{A} \\ \text { Деревьев нет и листьев нет, } & \mathrm{b} \\ \text { Горит вверху иллюминация } & \mathrm{A}^{\prime} \\ \text { Организованных планет, } & \underline{\mathrm{b}} \\ \text { И самолеты-вертолеты } & \mathrm{A} \\ \text { Гнездятся в верхних облаках, } & \mathrm{b} \\ \text { И где-то первые пилоты } & \mathrm{A} \\ \text { Лежат - пропеллер в головах, } & \underline{\mathrm{b}} \\ \text { И электричка рядом бродит, } & \mathrm{A} \\ \text { Огнями вытравляя мрак. } & \mathrm{b} \\ \text { И в белом платье тень приходит } & \mathrm{A} \\ \text { В Воздухоплавательный парк... } & \underline{\mathrm{b}}\end{array}$

Here he again basically uses an AbAb quatrain - with one A' rhyme word and iambic tetrameter (it is striking how traditional he is in much of this early poetry), and even though the fourth and eighth lines in this excerpt end with commas, the four pairs of lines each introduced by an "and" impart a syntactic regularity to the conclusion. As a result, the run-on between stanzas is not particularly striking.

As time goes on, in some of his poems without blank lines between stanzas Kushner continues to end all the rhyme sets with a strong syntactic break. However, more and more frequently he comes to leave some of his stanzas syntactically open. And at times he virtually ignores the border between stanzas. Thus in "I esli spish' na chistoj prostyne..." from the 1984 collection Tavricheskij sad, he has no periods after any of its four-line rhyme groups, so that only the rhyme scheme indicates the stanza structure:

$\begin{array}{ll}\text { И если спишь на чистой простыне, } & \mathrm{a} \\ \text { И если свеж и тверд пододеяльник, } & \mathrm{B} \\ \text { И если спишь, и если в тишине } & \mathrm{a} \\ \text { И в темноте, и сам себе начальник, } & \mathrm{B} \\ \text { И если ночь, как сказано, нежна, } & \mathrm{c} \\ \text { И если спишь, и если дверь входную } & \mathrm{D} \\ \text { Закрыл на ключ, и если не слышна } & \mathrm{c}\end{array}$




$\begin{array}{ll}\text { Чужая речь, и музыка ночную } & \mathrm{D} \\ \text { Не соблазняет счастьем тишину, } & \mathrm{e} \\ \text { И не срывают с криком одеяло, } & \mathrm{F} \\ \text { И если спишь, и если к полотну } & \mathrm{e} \\ \text { Припав щекой, с подтеками крахмала, } & \mathrm{F}\end{array}$

Here, in the first twelve of the poem's 20 lines, the fifth line simply continues the anaphora that starts with the beginning of the poem, imparting no hint of syntactic closure. This openness is taken further at the border of lines 8 and 9 , which I have highlighted in the quotation. For one thing, even though one line ending is feminine and the other masculine, in both the rhyme vowel is $u$, helping to link the two lines. More significantly, the adjective at the end of line 8 modifies the noun at the end of line 9, thus obliterating any sense of a syntactic boundary between the rhyme sets. Note that while an absence of syntactic closure between stanzas is not unusual, outright enjambment, as in this instance, appears far less often. ${ }^{8}$ Thus, in looking at Gumilev's graphically divided verse, Svetlana Matiash observed some 88 times when stanzas that were syntactically open but only two cases of actual enjambment - when there is no pause between lines or when a stronger break occurs within one of the lines rather than at the end. ${ }^{9}$ At the beginning of Kushner's career a poem with undivided stanzas that so radically dispenses with the notion of syntactic closure after each rhyme set would have gone very much against his inclinations. Meanwhile, even as he comes to vary the internal structures of his undivided poems, Kushner continues to place a clear syntactic break after essentially all of his stanzas when he divides them by blank lines.

Kushner's collection Kustarnik (2002) illustrates the range of his mature practice in this regard. For the more than 50 poems with blank lines placed between the stanzas, nearly every stanza ends with a period or other punctuation clearly marking the end of a sentence. A very few stanzas end with a colon or an ellipsis, but even in these instances the syntax appears "closed", and there are certainly no examples of outright enjambment. The several poems in which stanzas are not separated on the page present, on the whole, a very different picture. Just one, "Stena", contains a syntactic break after every four lines. A second such poem ends one $\mathrm{aBaB}$ rhyme group with a comma and the other

8 Dictionary definitions of enjambment vary and can be incomplete; for a brief summary of its varieties see Scherr 1986: 264-265.

9 The number 88 is derived from the percentage of open stanzas in the table provided in Matiash 2009: 196. 
two with sentence breaks. The third, "On snimaet zdes' dachu, znakomy...", contains 36 lines (with a space between lines $2 / 3$ of the way through) and four of the eight rhyme sets that precede the last end with punctuation no stronger than a comma, thus indicating syntactic openness. Two of those instances have no punctuation at all and comprise clear examples of enjambment. The most extreme play with the expected correspondence of rhyme set borders and syntactic breaks occurs in "Pobochnye deistvija", where the absence of spaces between the stanzas presents just one of several challenges to the poem's readers: the layout of the poem (in columns that break up most of the lines into smaller sections), the irregular numbers of feet in the lines of verse, and the lack of sentence breaks throughout the poem all factor as well into masking the structure. The first half of the poem appears on the page as 22 separate lines; only the first and sixth of these are full lines of verse:

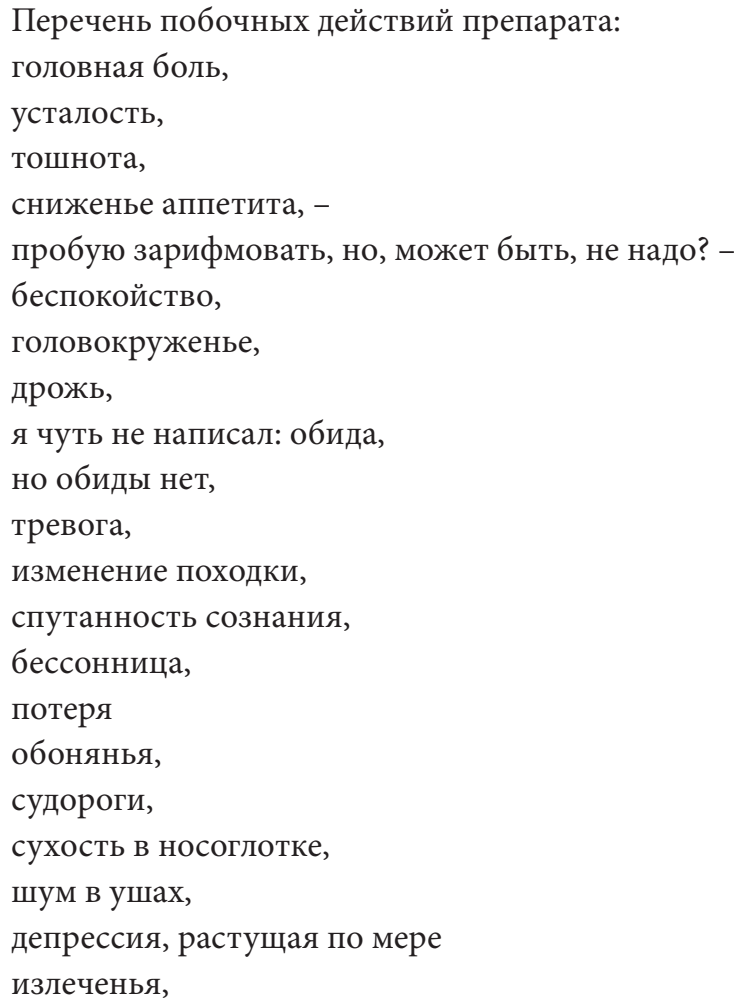

The poem is written in trochaic lines, which contain anywhere from five to ten feet. Despite the hesitation expressed in the sixth line of the quotation, "Pobochnye dejstvija" is rhymed throughout, and these rhymes allow 
for the possibility of locating the actual borders between lines and for determining that the work consists of quatrains in alternating feminine rhyme (ABABCDCD...):

Перечень побочных действий препарата:

головная боль, усталость,тошнота, сниженье аппетита, -

пробую зарифмовать, но, может быть, не надо? -

беспокойство, головокруженье, дрожь, я чуть не написал: обида,

но обиды нет, тревога, изменение походки,

спутанность сознания, бессонница, потеря обонянья,

судороги, сухость в носоглотке,

шум в ушах, депрессия, растущая по мере излеченья,

Note that the D rhyme exhibits consonance - i.e., the stressed vowels in the rhyme words differ. The poem as a whole occupies 36 lines on the page, but only contains sixteen lines of verse. The third of the four rhyme units concludes with a question mark, but that is at the end of a parenthetical phrase appearing between dashes while the main clause continues into the next line (indeed, the entire poem essentially consists of a single sentence). In all, the poem conveys as well as any the way in which a tension between the natural "closedness" of stanzas on the one hand, and, on the other, the openness of a work's syntactic structures as well as its graphic layout can contribute to the overall effect of a poem. Most importantly, though, the poem exhibits a radical quality in its formal experimentation that is relatively extreme for Kushner: like Rein, though more in his later than his earlier poetry, he appears to find a certain freedom in writing verse where the rhyme sets are not demarcated on the page.

This study has touched on two phenomena that require much further research. Nonetheless, it is possible to form some initial hypotheses from the material examined here. First, subtle (and in some cases not so subtle) formal features that strengthen the integrity of the given stanza often become evident upon close analysis. Hence, over the length of a poem an 8-line stanza that rhymes, say, $\mathrm{AbAbCdCd}$, is likely to display rhythmic or syntactic structures that militate against its division into two quatrains. Exceptions certainly exist, but poets for the most part find ways, perhaps as much unconsciously as consciously, to make the stanza they have chosen central to the poem's structure. And the same point, again with certain exceptions, applies to the potential clustering of stanzas into longer units: when poets employ 2-, 4- or 6-line stanzas, they typically will use formal elements that help delineate the stanza boundaries and 
prevent their being perceived as larger structures. However, as we have seen in the case of Gumilev, 2-line stanzas - given their brevity - are more likely than other lengths to combine into longer units: the placement of syntactic boundaries along with certain rhythmic qualities sometimes suggest that the basic structure of a particular poem consists of longer stanza forms.

Second, the decision to use repeated rhyme patterns but not to demarcate their boundaries on the page often carries with it certain ramifications. The most obvious and the most widespread of these is the sense that it is less necessary to have strong syntactic boundaries coincide with the ends of rhyme units. When poets place blank lines between their stanzas, they typically make the great majority of the stanzas syntactically closed - generally, more than $80 \%$, and for some poets more than $95 \%$. When graphic breaks do not exist, poets may still place syntactic breaks after each rhyme unit within a given poem, but at other times they will allow for syntactically open structures to appear at the boundaries of rhyme units. This lack of closure will be less marked than when it appears between separated stanzas and allows for a greater flexibility in shaping a work's narrative, with topics more easily allotted varying amounts of space or with the work as a whole running on as though forming a single continuous statement. Other consequences of not separating the stanzas may be subtler. Poets like Rein and Kushner, who write substantial amounts of verse in stanzas that are not divided on the page, can be stricter than most in observing syntactic closure when they do place blank lines between stanzas. When he does not separate his stanzas on the page, Rein tends to employ a wider range of meters and to be more experimental in his rhyming; for his part, Kushner turns to structures that are more varied and complex than those found in his other stanzaic verse. However, the crucial feature seems to be the greater freedom: be it to create a more varied internal structure, employ a wider range of forms, or carry out more extreme experiments.

In general, verse scholars to date have devoted most of their attention to such features as verse rhythm, rhyme and syntax, while not deeply examining the internal workings of stanzas and how the choice of stanza form can affect other aspects of a poem. The intent of this article has been to suggest that even such a seemingly trivial matter as the way in which stanzas are separated (or not separated) on the page may carry with it significant implications for the formal qualities exhibited by a work. To date the investigation of this topic has been confined to relatively few poets and works; further studies of these matters among individual poets from various eras will be needed to know whether it is possible to discern the existence of norms that have governed the role played by graphic divisions over the history of Russian verse. 


\section{References}

Dewey, John 2010. Mirror of the Soul: A Life of the Poet Fyodor Tyutchev. Shaftesbury: Brimstone Press.

Fedotov, Oleg 2002. Osnovy russkogo stikhoslozhenija: Teorija i istorija russkogo stikha, kniga 2: Strofika. Moskva: Flinta, Nauka.

Gasparov, Mikhail 1989. Stroficheskij ritm v russkom 4-stopnom jambe i khoree. In: Scherr Barry P.; Worth, Dean S. (eds.), Russian Verse Theory: Proceedings of the 1987 Conference at UCLA. Columbus, Ohio: Slavica, 133-147.

Gumilev, Nikolay 1988. Stikhotvorenija i poemy. Leningrad: Sovetskij pisatel'.

Gumilev, Nikolay 1999. Polnoe sobranie sochinenij v desiati tomakh, 3. Moscow: Voskresen'e.

Häublein, Ernst 1978. The Stanza. London: Methuen \& Co.

Kushner, Aleksandr 2002. Kustarnik: Kniga novykh stikhov. St. Petersburg: Pushkinskij fond.

Laletina, Ol'ga; Lutsiuk, Irina; Tver'ianovich, Kseniia 2008. Metrika i strofika A. S. Kushnera. In: Khvorost'ianova, Elena (ed.), Peterburgskaja stikhotvornaja kul'tura: Materialy po metrike, strofike i ritmike peterburgskikh poetov. Sankt-Peterburg: Nestor-Istorija, 517-634.

Matiash, Svetlana 2009. Stroficheskij perenos v russkoj poezii (voprosy teorii i istorii). In: Skulacheva; Tatiana; Prokhorov, Aleksandr (eds.), Slavianskij stikh, VIII: Stikh, jazyk, smysl. Moskva: Jazyki slavianskoj kul'tury, 192-210.

Rein, Evgeny 2001. Izbrannye stikhotvorenija i poemy. Moskva, Sankt-Peterburg: Letnij sad.

Shakhverdov, Sergei 1979. Metrika i strofika E. A. Baratynskogo. In: Gasparov, Mikhail (ed.), Russkoe stikhoslozhenie XIX v.: Materialy po metrike i strofike russkikh poetov. Moskva: Nauka, 278-328.

Scherr, Barry 1986. Russian Poetry: Meter, Rhythm, and Rhyme. Berkeley: University of California Press.

Scherr, Barry in press-a. Nerazdelennyj stikh Evgeniia Reina.

Scherr, Barry in press-b. Seeing the Forest through the Trees: The Underlying Structure of Gumilev's “Les”.

Tomashevsky, Boris 1958. Strofika Pushkina. In: Pushkin: Issledovanija i materialy 2, 49-184. 
Vishnevsky, Kirill 1978. Arkhitektonika russkogo stikha XVIII - pervoj poloviny XIX veka. In: Kholshevnikov, Vladislav (ed.), Issledovanija po teorii stikha. Moskva: Nauka, 48-66. 